\title{
Neurocognitive impairment and gray matter volume reduction in HIV-infected patients(Abstract_要 旨)
}

AUTHOR(S):

Kato, Tadatsugu

\section{CITATION:}

Kato, Tadatsugu. Neurocognitive impairment and gray matter volume reduction in HIVinfected patients. 京都大学, 2020, 博士(医学)

\section{ISSUE DATE:}

2020-09-23

URL:

https://doi.org/10.14989/doctor.r13372

\section{RIGHT:}

許諾条件により本文は2021-08-31に公開; This is a post-peer-review, pre-copyedit version of an article published in Journal of NeuroVirology. The final authenticated version is available online at: http://dx.doi.org/10.1007/s13365-020-00865-w 


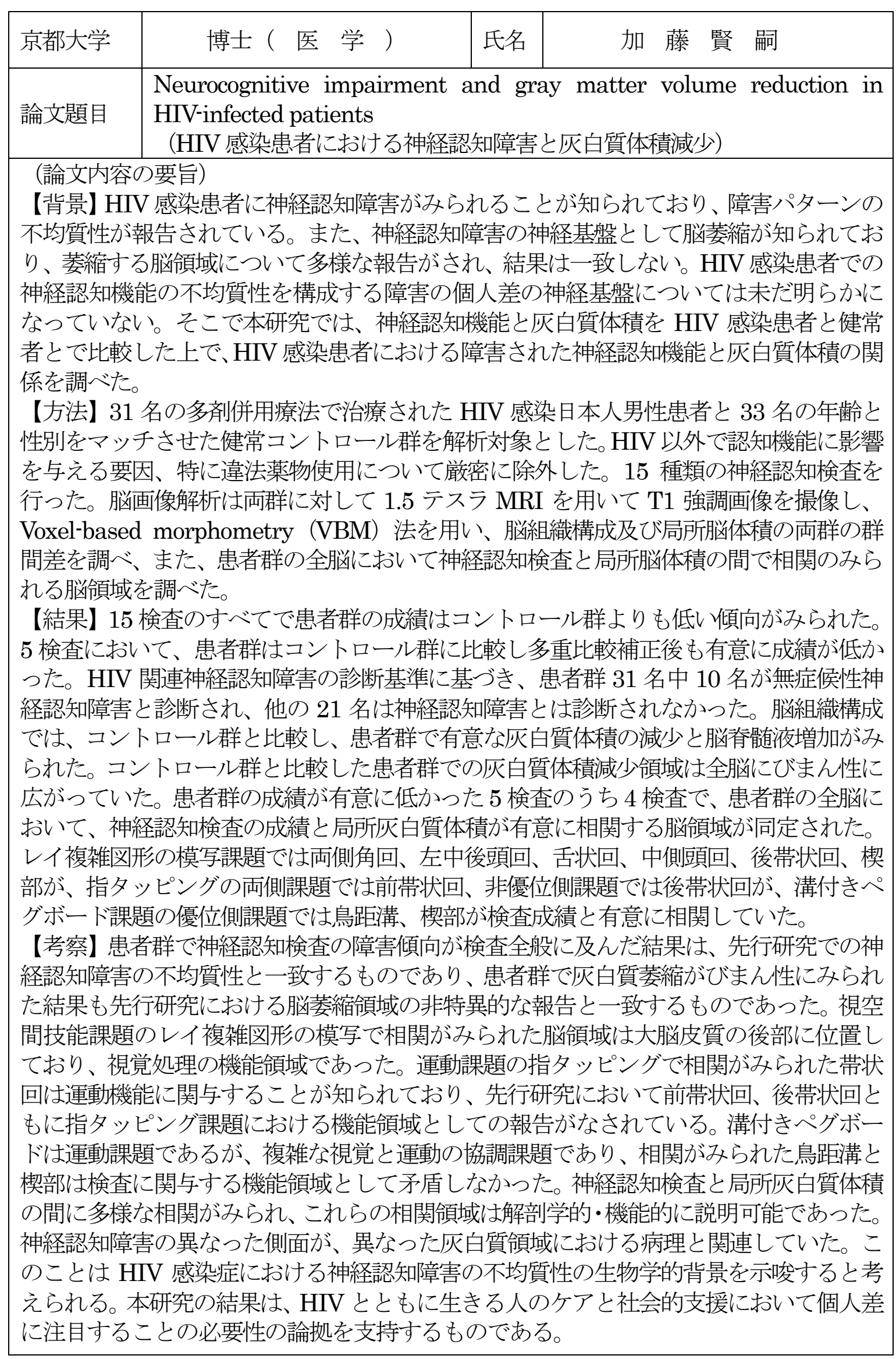

(論文審査の結果の要旨)

HIV 関連神経認知障害の不均質性が報告され、多様な認知機能が障害される可能性を 踏まえた上で、個人差に配慮する患者支援が求められている。しかし、HIV 感染患者の 神経認知障害の不均質性が脳萎縮という神経基盤を伴っているかは明らかでなかった。

本研究では、31 名の HIV 感染患者と 33 名の健常被験者を対象とし、違法薬物の交 絡を厳密に除外し、神経認知検査と MRI での T1 強調画像撮像を行い、voxel-based morphometry（VBM）法を用いて、群間比較（神経認知検査、脳組織構成、局所灰白 質体積）を行った。さらに、患者群で、神経認知検査と局所灰白質体積の相関領域を調 べた。患者群全体では、神経認知障害の認知領域特異性は乏しく、灰白質体積减少領域 の分布はびまん性であった。一方で、個別の神経䏠知検査成績は、異なる灰白質領域の 体積との間に相関がみられていた。すなわち、HIV 関連神経認知障害の異なる側面が異 なる灰白質領域の病理と関連し、神経認知障害の不均質性の背景に神経基盤が伴ってい ることが示唆された。

以上の研究は HIV 感染患者の神経認知障害の不均質性の神経基盤の解明に貢献し、 HIV 関連神経認知障害の理解及びその支援に寄与するところが多い。

したがって、本論文は博士 (医学) の学位論文として価值あるものと認める。

なお、本学位授与申請者は、令和 2 年 8 月 27 日実施の論文内容とそれに関連した試 問を受け、合格と認められたものである。 